\title{
Community Adaptation to Traditional Markets during the Pandemic Period in Palembang City
}

\author{
Hendi Warlika Sedo Putra ${ }^{1, *}$ Maya Fitri Oktarini ${ }^{2}$ Primadella $^{2}$ \\ ${ }^{1}$ Department of Civil Engineering, Politeknik Negeri Sriwijaya, Indonesia \\ ${ }^{2}$ Department of Architecture, Engineering Faculty, Universitas Sriwijaya, Indonesia \\ ${ }^{*}$ Corresponding author. Email: hendiwsp@polsri.ac.id
}

\begin{abstract}
The traditional market is one of the main facilities for the community to obtain daily food needs, as a place to sell wet food, dry food, and ready-to-eat food ingredients that is difficult to replace with existing modern markets. During the Covid-19 pandemic, traditional markets have the potential to be a locus in the spread of the virus because of activities that invite crowds. However, buying and selling activities in traditional markets must continue to supply the daily needs of the community, and to support the economic sustainability of the poor society. Government plans and directions for meeting the community needs in the smallest neighborhood or RT (Rukun Tetangga) did not implemented during the PSBB (large-scale social restrictions) period in Palembang. It can be seen that there are still many people whose shop at traditional markets. For this reason, it is necessary to organize the implementation of economic activities in traditional markets by applying public health priorities. This study examines the adaptations made by community of Palembang City in traditional markets during the Covid-19 pandemic. That is done by observing the fulfillment of health protocol support facilities in the market environment, the form of adjustment to health protocol directives, and the comfort and health aspects in terms of the technical aspects of traditional market buildings. The results of this study become the basis for the development of traditional market building standards in accordance with health protocols (in setting policies, fostering business activities, and supervising), including the pattern of traditional market spaces, facilities and infrastructure adapted to the behavior of the local community.
\end{abstract}

Keywords: traditional markets, spatial patterns, new life arrangements, healthy markets, facilities, health protocols.

\section{PRELIMINARY}

The market is a facility for the community to make it easier to get their daily needs and as a public space for buying and selling activities. There are around 36 retail market types scattered in all sub-districts in Palembang City, all of which operated during the Covid-19 pandemic. The role of traditional markets as a trading facility is difficult to replace with other modern markets even though the products and trading materials are the same. Traditional markets are closely related to the culture of the community that interacts between sellers and buyers. People like to buy in traditional markets because buying and selling is done through a bargaining process to get a lower price and the freshness of basic commodities. Therefore, government directives through the Ministry of Health to limit movement on the RT / RW / Village scale are difficult to implement in order to replace market functions.

This condition causes conflict between providing community needs or being able to protect the community in the spread of Covid-19 in the community. The market is one of the locations with great potential as the center of the spread of Covid-19. The government through the Decree of the Minister of Health of the Republic of Indonesia number HK.01.07 / MENKES / 382/2020 concerning Health Protocols for Communities in Public Places and Facilities in the Context of Prevention and Control of Corona Virus Disease 2019 (covid-19) provides rules or directions for the community, market managers (government / related agencies) in activities in traditional markets. Implementation of some health protocols is very difficult to do in a market environment. 
Health protocols require the provision of a place to wash hands, limit crowd, and maintain distance and use of masks. This study will examine the adaptations made by the community to implement these health protocols in traditional markets.

The concept of a healthy market was actually issued by the government long before the pandemic occurred through the spread of the Covid 19 virus. The market can be a place for the spread of vectors of disease transmission. Therefore, policies related to healthy markets are stated in the Decree of the Minister of Health number 519 of 2008 , namely division of trade zones and arrangement of selling spaces. The division of the trade zone adjusts the types of commodities based on their characteristics and classification, while the arrangement of the trading space discusses the details of places for selling food.

The government divides healthy market zones based on the types and characteristics of the materials being traded. Each market has separate dry and wet zones. Each zone must be easily identified with a clear identity or marker, especially for the zone for selling meat, poultry and fish, considering that these types of selling materials require special treatment. Another rule relates to the stall aisle width of at least 1.5 meters with each booth having an identity board. The distance between the shelter and slaughterhouse for poultry with the main building is at least 10 meters or limited by a parapet with a minimum height of 1.5 meters. Especially for hazardous and toxic materials or pesticides, they must be placed separately and not adjacent to the food zone.

Detailed arrangement of the place of sale, especially food and food ingredients, which includes the arrangement of wet food ingredients. Each booth has a counter with a flat surface with a sufficient slope so that it does not create puddle and there is available drain hole. Each side of the booth is separated by a divider which is designed to be cleaned easily with a height of the sales table at least $60 \mathrm{~cm}$ from the floor. The serving of meat must be hung. Each booth provides a storage area for food, fish and meat using cold chain or low temperature. In each market, there must be a washing place for foodstuffs and utensils and a hand washing place with soap and running water. Sewerage is built closed with a slope according to applicable regulations.

During Covid 19 pandemic, the government through the Minister of Health made special decision on health protocols for community in public places and facilities to adapt new habit. The general principles of health protocols directed by the government lead to the concept of adaptation to new, healthier and cleaner habit to be implemented by all components in society and empowering all existing resources. The government specifically regulates several points of rules to apply in traditional markets including physical changes to market buildings and adaptation of community behavior. These rules are the use of masks, maintain distance from other people, and maintain hand hygiene. The regulations also regulate the procedures for traders to apply a distance in the market area and provide adequate hand washing facilities with soap that are easily accessible to traders and visitors. In addition, buildings also need to pay attention to the air quality of shopping centers by optimizing air circulation and sunlight and providing open space for sales or transaction places to prevent crowds. The regulation also adds health facilities by providing a special room or health post for first treatment.

Circulation space is an important physical space in traditional markets. It is also a commercial space which has an influence on the relationship between visitors and merchandise displays, as well as between visitors (Julius Panero M.Z., 2003). The dimensions of the circulation space required are between $167.6 \mathrm{~cm}-304.8 \mathrm{~cm}$ depending on the conditions of visitor interaction and merchandise displays. Other physical arrangements include ventilation and natural lighting as optimizing solar lighting and ventilation without using a mechanical system.

The current problem is how the implementation of government regulations related to health protocols in the market environment can be applied, especially in traditional markets in Palembang city. In general, health protocols are very difficult to implement in a market environment. An example of a problem that can be seen is the lack of discipline in the community to wash their hands in a market environment, even though the facilities for washing hands are already provided at every entrance to traditional markets in Palembang. Another problem that is no less important is the negative stigma that has formed in the community regarding the impression that traditional markets are slum, dirty, smelly, and irregular pattern.

Another consideration is the duration of the pandemic which may not be experienced throughout the year by the people of Palembang city in particular, its mean changes that may be in conditions at this time may turn into negative values in the future. On the other hand, we must also be able to consider and see, the extent to which the concept of a healthy market is contained in the Decree of the Minister of Health number 519 of 2008 concerning the arrangement of trade spaces and places for selling food and food. These considerations are important as a basis for conducting research "Adaptation of Spaces and Organizing Facilities for Traditional 
Markets in the New Normal Era of Palembang City". In more detail, we can see the pattern of implementing health protocols in the market environment and also the suitability that has been directed by the government to make traditional markets a healthy market concept.

\section{RESEARCH METHODS}

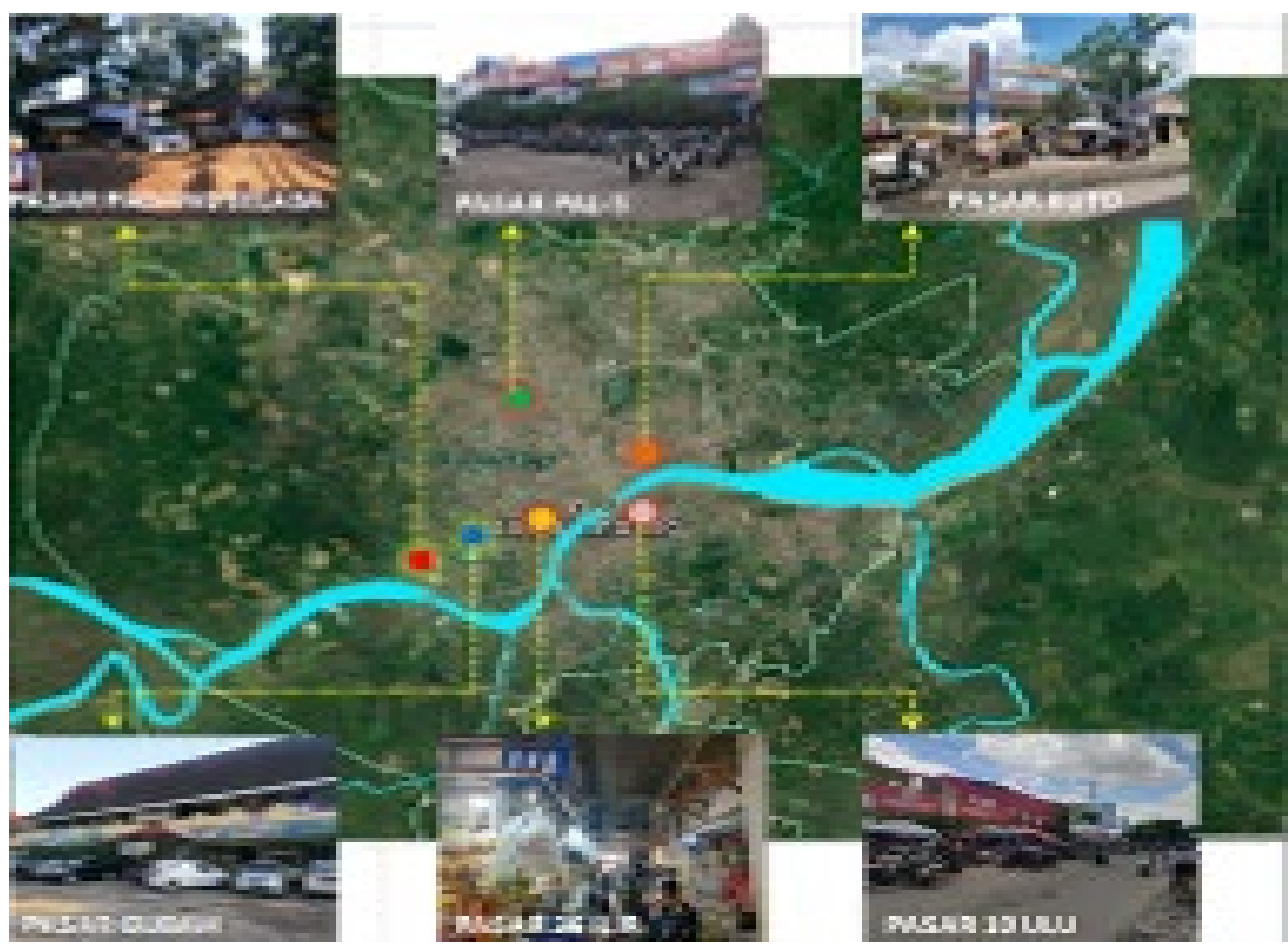

Figure 1. Distribution of research areas

Primary data is the result of identification of the existing market conditions. Physical and non-physical data in the form of: availability of hand washing facilities, availability of signs / guides for visitors in the circulation room, the presence of bulkheads between traders, conditions of sewage, placement of market traders, lighting systems and air circulation in the market, and user behavior. Secondary data is in the form of regulations issued by the government as well as theories related to health protocols in traditional market areas. The analysis model used is descriptive qualitative research. The aim is to present empirical facts well regarding the suitability or form of adaptation that has been applied in several traditional markets in Palembang City.
This study used a comparative study method by examining the suitability of market samples taken with the theory and regulations that direct the health protocol. This method is expected to provide an overview of the suitability of market building adaptation to health protocol during the Covid-19 pandemic. The samples were taken from several markets in Palembang, namely: Pasar Padang Selasa, Pasar Gubah, Pasar 26 Ilir, Pasar Pal-5, Pasar Kuto, and Pasar 10 Ulu. 


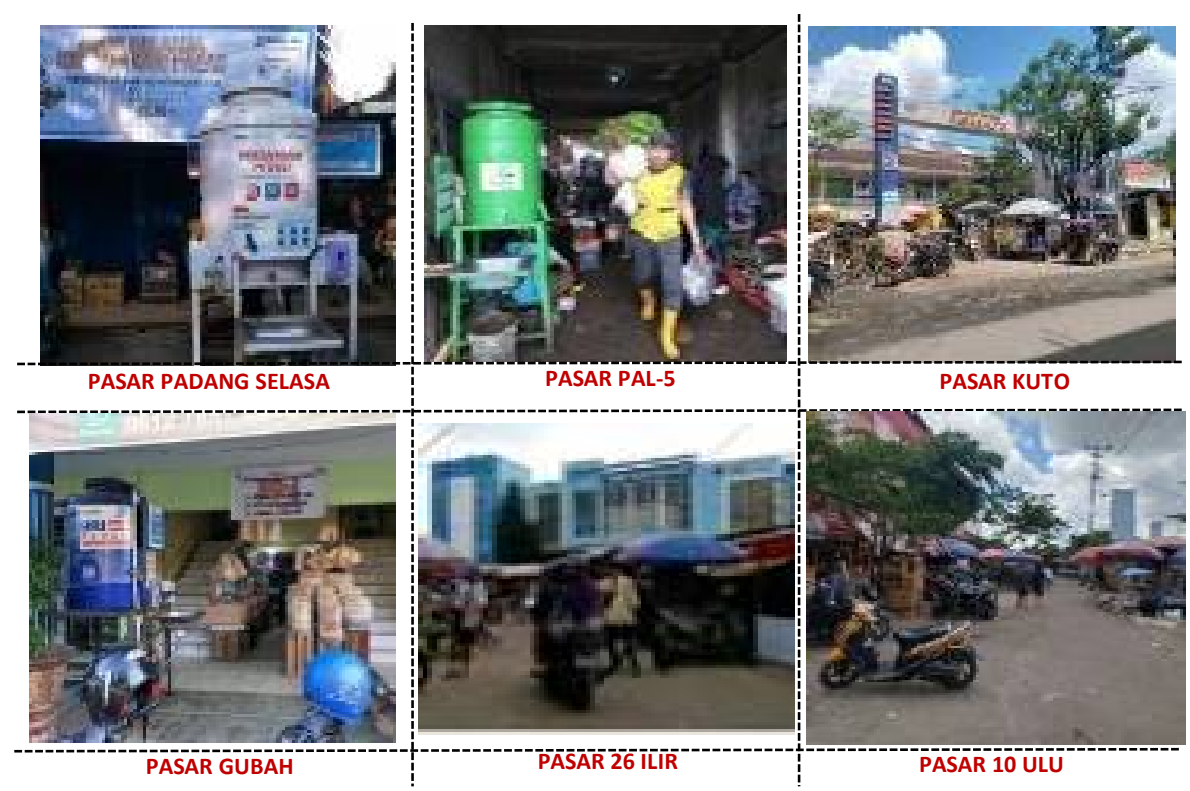

Figure 2. Handwashing with Soap in Traditional Markets

\subsubsection{Visitor Circulation Space.}

The dimension of the circulation space in the market is very important during the Covid-19 pandemic. According to government directives for health protocols, visitors and market users should be able to maintain a minimum distance of 1 meter between visitors. From observations (figure 3), most markets have circulation space that meets the space standards. Some markets have circulation space not more than $80 \mathrm{~cm}$ wide. Another problem in implementing health protocols through circulation space is that almost all traders use circulation space to place merchandise, as seen in the circulation space of Padang Selasa market, Pal-5 market, 26 Ilir market, and 10 Ulu market. This has an impact on the shrinking of market circulation space that can be used by market visitors. This condition must be a concern for market managers to discipline traders for placing merchandise in the market space or booth so that it does not disturb the circulation space in the market.

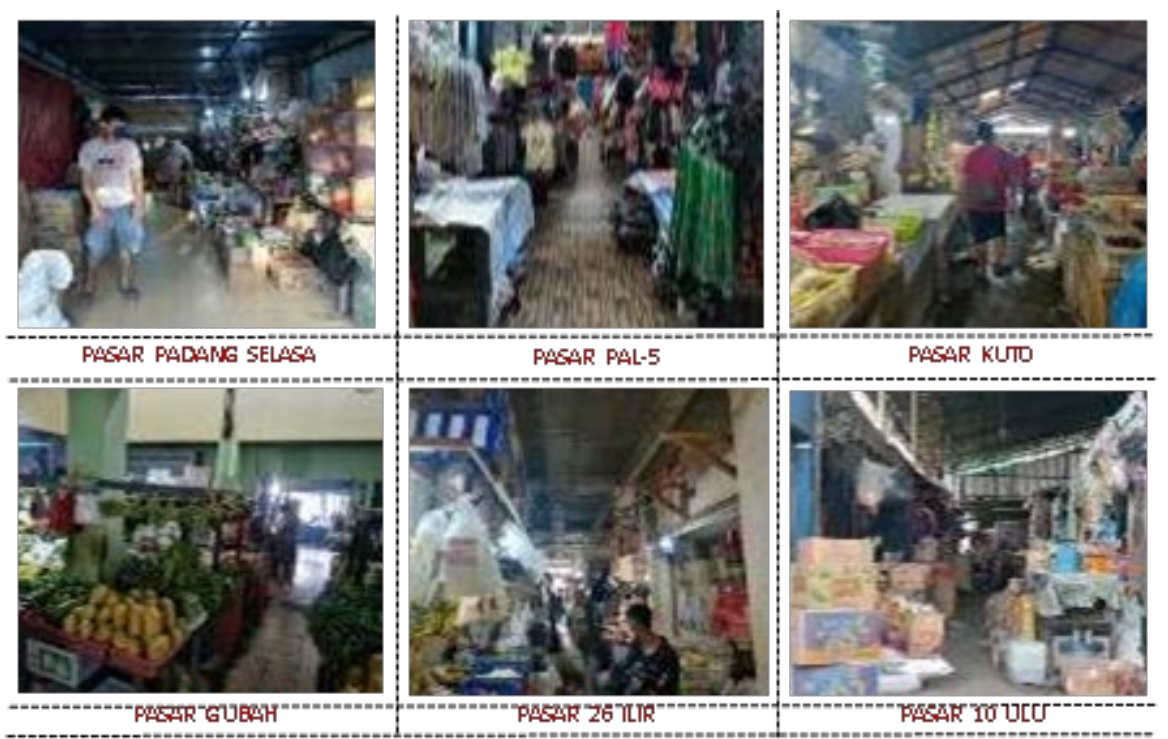

Figure 3. Circulation Room in Traditional Markets

1.1.3. Limitation of bulkheads between traders, use of masks, and the application of distances between visitors.
Other directives in physical health protocols are by setting bulkheads between traders, and non-physical health directions for market activities, such as using masks by visitors and traders, and maintaining distance during activities in the market. 


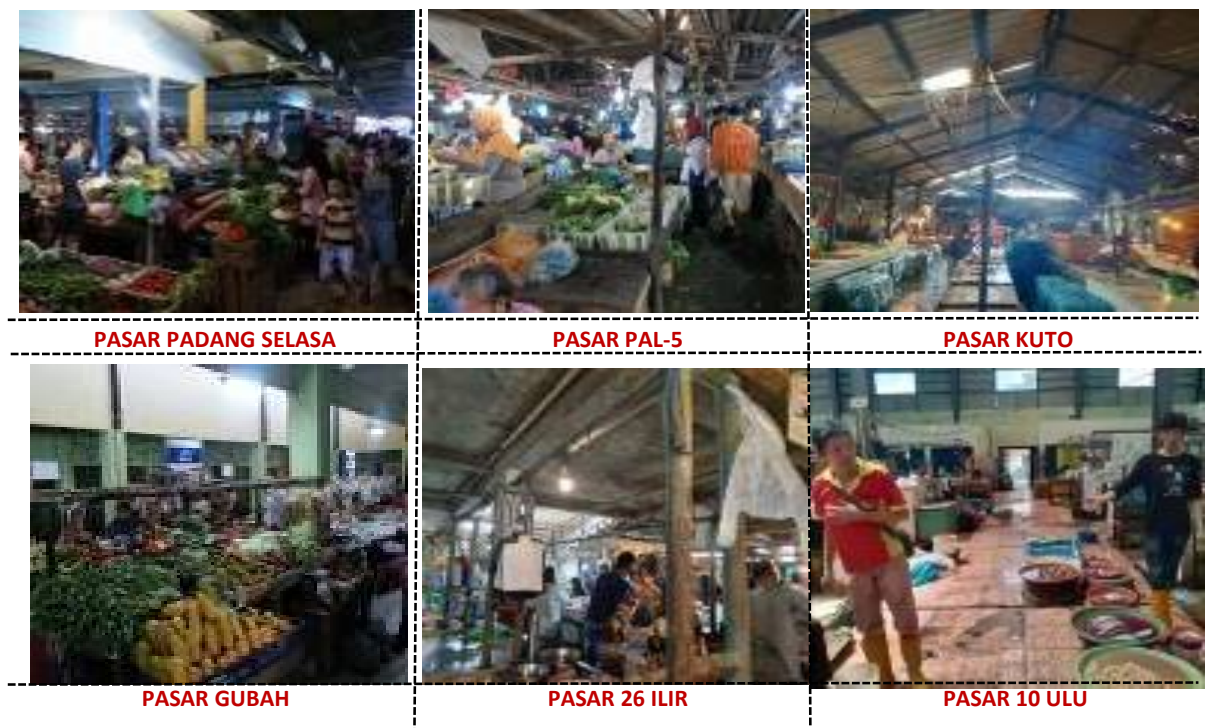

Figure 4. Activities in Traditional Markets

From this description, it is found that not all visitors and market traders comply with government regulations for wearing masks during activities in the market (figure 4). This is closely related to public awareness to behave and be disciplined in minimizing the spread of COVID19 in the community. For this reason, it is very necessary to take action by the government to provide understanding to the community regarding the importance of maintaining health by implementing health protocols. The difficulty in implementing health protocols in a market is caused by the crowds of market visitors who are not directly related to the availability of sufficient circulation space in the market. As seen in Padang Selasa market and also Pal-5 market, where the circulation space in the market is not enough to accommodate visitors. This is also related to the use of public space (circulation) by traders to place their merchandise. The application of social distancing in the market area is also not supported by the presence of markers or signs in the form of stickers on the market floor as information. The application of these stickers is also constrained by the condition of the market floor, which is not all good, dry and clean. On the other hand, the use of bulkheads between traders is also not carried out by traditional market managers, where traders who occupy the stall type should be given a bulkhead that can minimize the spread of the virus in accordance with the direction of health protocols, but does not limit social interactions between traders. This should be the task of market managers in implementing health protocols.

\subsubsection{Air circulation / ventilation and natural lighting.}

Judging from the existing conditions, some traditional markets have quite poor natural lighting and ventilation. Some of the problems are the low roof height of the market buildings which causes the air space to become smaller and the market feels more crowded. This can be seen in the Pasar Padang Selasa (figure 5). In addition, the circulation space which should have the potential to enter direct sunlight is widely used by covering it with a roof to secure merchandise. In Pasar 26 Ilir, the building is large enough to prevent the sun from entering the building maximally because the distance is quite far from the edge of the building. So that traders often use lamps on the first floor of the building. The air circulation system is also not good, there are many buildings that block the air flow into the market buildings. Good examples can be seen at figure 5 from Pasar Pal-5, Pasar 10 Ulu, and Pasar Gubah where these markets have high roofs, so that the air pockets in the buildings are also quite large. In addition, the market also has an atrium in the middle of the building (Pasar Gubah and Pasar Pal-5) which is used as a cross ventilation space for natural air, as well as natural lighting which is circumvented by entering sunlight from the atrium gap and the use of transparent materials on the roof covering of the building. 


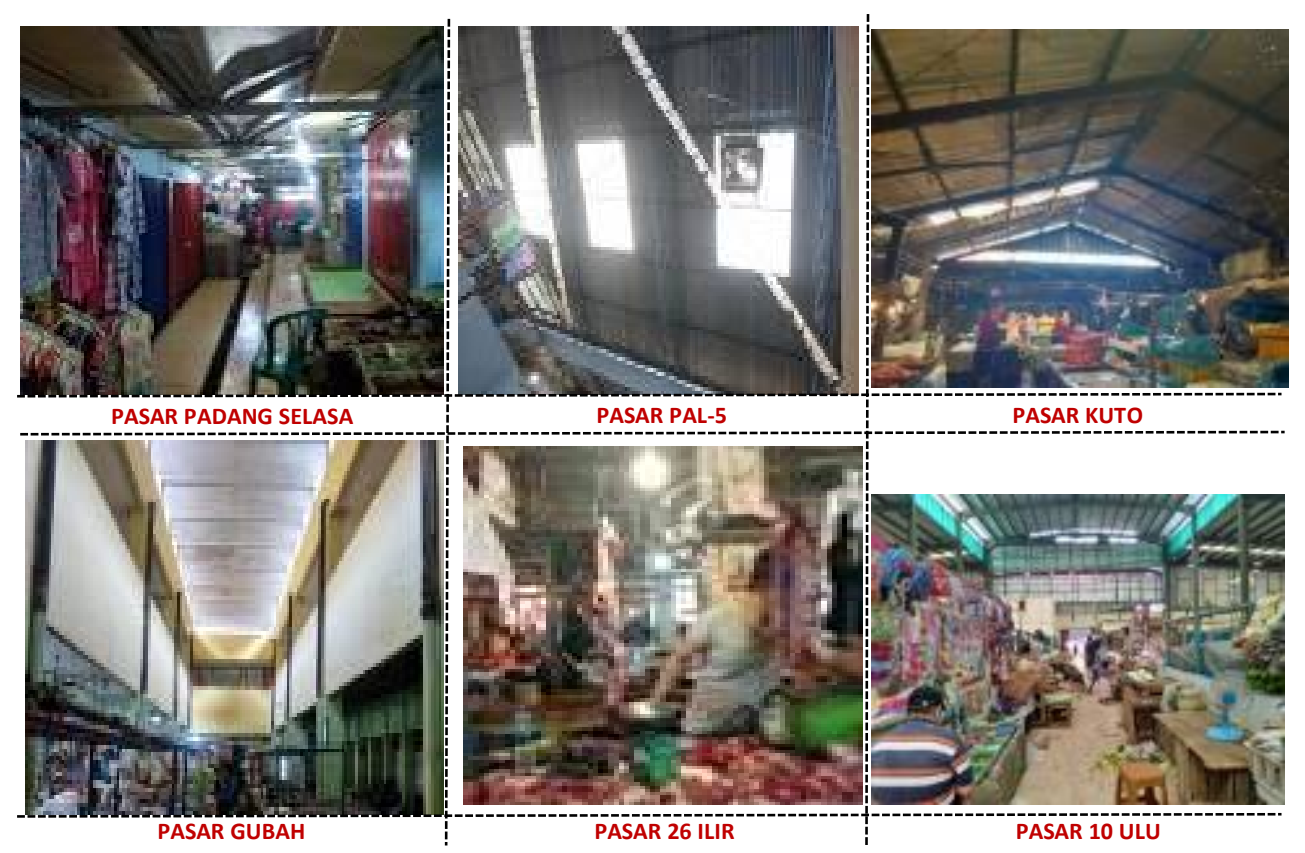

Figure 5. Natural Lighting and Ventilation in Traditional Markets

\subsubsection{Sewage Drain.}

As directed by the government for implementing a healthy market, one of the most important points is that the market has a closed sewerage drain. From the results of field observations almost the entire market has open sewers so that the strong odor generated from the drain is smelled in all areas of the market. It can be seen in figure 6, Pasar Padang Selasa was combines hazardous waste (slaughtered animal waste) into existing channels in the market. This is dangerous when every existing market does not have Wastewater Treatment Plant (WWTP) to be processed before being discharged into the residential area or city. A good example can be seen in Pasar Gubah, although with non-permanent (wooden) cover, the chicken and fish selling have closed drain (figure 6; Gubah market). Another example that is quite good is Pasar Pal-5. The market floor is sloped towards the sewer, so that the market floor can still be maintained the dryness and eliminate the impression of being slum.

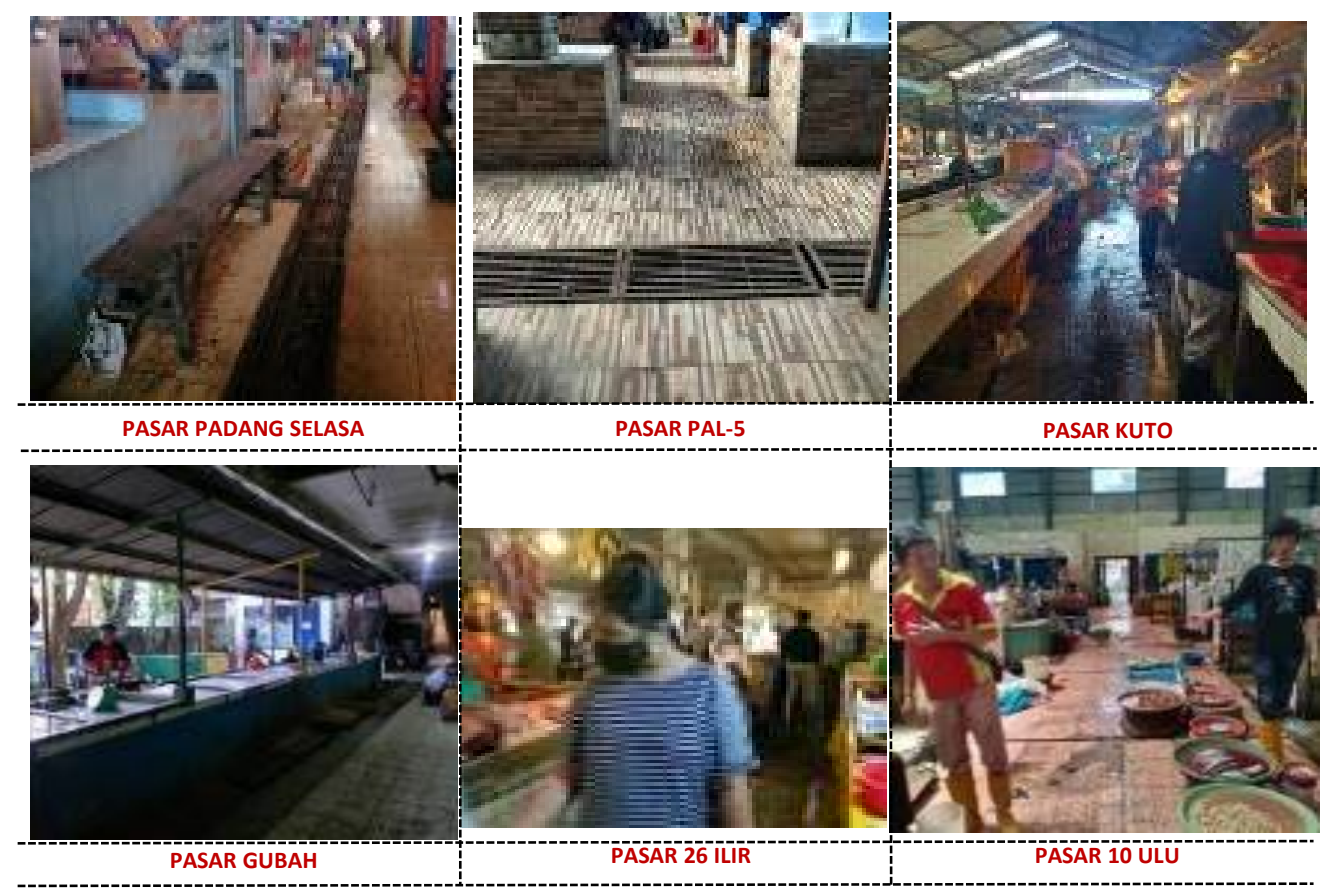

Figure 6. Sewerage in Traditional Markets 


\subsection{Suitability of Health Protocol Application}

Tabel 1. Suitability of Health Protocol Application in Market Environment

\begin{tabular}{|c|c|c|c|c|c|c|c|c|c|c|c|c|c|c|}
\hline \multirow{2}{*}{ No } & \multirow{2}{*}{ Health Protocol Directives } & \multicolumn{2}{|c|}{$\begin{array}{l}\text { Pasar Padang } \\
\text { Selasa }\end{array}$} & \multicolumn{2}{|c|}{ Pasar Gubah } & \multicolumn{2}{|c|}{ Pasar Pal-5 } & \multicolumn{2}{|c|}{ Pasar 26 Ilir } & \multicolumn{2}{|c|}{ Pasar Kuto } & \multicolumn{2}{|c|}{ Pasar 10 Ulu } & \multirow{2}{*}{$\begin{array}{l}\text { Average } \\
\text { Obedience }\end{array}$} \\
\hline & & $\begin{array}{c}\text { Exists/ } \\
\text { Good }\end{array}$ & $\begin{array}{c}\text { Not } \\
\text { Exists/ } \\
\text { Bad }\end{array}$ & $\begin{array}{l}\text { Exists/ } \\
\text { Good }\end{array}$ & $\begin{array}{c}\text { Not } \\
\text { Exists/ } \\
\text { Bad }\end{array}$ & $\begin{array}{c}\text { Exists/ } \\
\text { Good }\end{array}$ & $\begin{array}{c}\text { Not } \\
\text { Exists/ } \\
\text { Bad }\end{array}$ & $\begin{array}{l}\text { Exists / } \\
\text { Good }\end{array}$ & $\begin{array}{c}\text { Not } \\
\text { Exists/ } \\
\text { Bad }\end{array}$ & $\begin{array}{l}\text { Exists/ } \\
\text { Good }\end{array}$ & $\begin{array}{c}\text { Not } \\
\text { Exists/ } \\
\text { Bad }\end{array}$ & $\begin{array}{c}\text { Exists } / \\
\text { Good }\end{array}$ & $\begin{array}{l}\text { Not } \\
\text { Exists/ } \\
\text { Bad }\end{array}$ & \\
\hline $\mathbf{A}$ & \multicolumn{14}{|l|}{ Amenities } \\
\hline 1 & $\begin{array}{l}\text { Provision of washing hands facility } \\
\text { with soap in front of building }\end{array}$ & $\sqrt{ }$ & & $\sqrt{ }$ & & $\sqrt{ }$ & & $\sqrt{ }$ & & $\sqrt{ }$ & & $\sqrt{ }$ & & $100 \%$ \\
\hline 2 & Signage on the market floor & & $\sqrt{ }$ & & $\sqrt{ }$ & & $\sqrt{ }$ & & $\sqrt{ }$ & & $\sqrt{ }$ & & $\sqrt{ }$ & $0 \%$ \\
\hline 3 & $\begin{array}{l}\text { Up and down direction sign on the } \\
\text { stairs }\end{array}$ & - & - & & $\sqrt{ }$ & & $\sqrt{ }$ & & $\sqrt{ }$ & & $\sqrt{ }$ & & $\sqrt{ }$ & $0 \%$ \\
\hline B & \multicolumn{14}{|l|}{ Infrastructure } \\
\hline 4 & $\begin{array}{l}\text { Limitation of bulkheads between } \\
\text { traders }\end{array}$ & & $\sqrt{ }$ & & $\sqrt{ }$ & & $\sqrt{ }$ & & $\sqrt{ }$ & & $\sqrt{ }$ & & $\sqrt{ }$ & $0 \%$ \\
\hline 5 & $\begin{array}{l}\text { Sewage Drain (closed channel and } \\
\text { flows) }\end{array}$ & & $\sqrt{ }$ & $\sqrt{ }$ & & $\sqrt{ }$ & & $\sqrt{ }$ & & & $\sqrt{ }$ & $\sqrt{ }$ & & $67 \%$ \\
\hline 6 & $\begin{array}{l}\text { Domination of traders outside the } \\
\text { building }\end{array}$ & & $\sqrt{ }$ & & $\sqrt{ }$ & $\sqrt{ }$ & & $\sqrt{ }$ & & $\sqrt{ }$ & & $\sqrt{ }$ & & $67 \%$ \\
\hline 7 & Natural lighting in buildings & & $\sqrt{ }$ & $\sqrt{ }$ & & $\sqrt{ }$ & & $\sqrt{ }$ & & & $\sqrt{ }$ & $\sqrt{ }$ & & $67 \%$ \\
\hline 8 & Building Air circulation / ventilation & & $\sqrt{ }$ & $\sqrt{ }$ & & $\sqrt{ }$ & & & $\sqrt{ }$ & & $\sqrt{ }$ & $\sqrt{ }$ & & $50 \%$ \\
\hline $\mathbf{C}$ & \multicolumn{14}{|l|}{ Behavior } \\
\hline 9 & $\begin{array}{l}\text { Buyers and traders use of masks or } \\
\text { faceshield }\end{array}$ & $\sqrt{ }$ & & $\sqrt{ }$ & & $\sqrt{ }$ & & & $\sqrt{ }$ & & $\sqrt{ }$ & & $\sqrt{ }$ & $50 \%$ \\
\hline 10 & $\begin{array}{l}\text { The application of distances between } \\
\text { visitors }\end{array}$ & & $\sqrt{ }$ & & $\sqrt{ }$ & & $\sqrt{ }$ & & $\sqrt{ }$ & & $\sqrt{ }$ & & $\sqrt{ }$ & $0 \%$ \\
\hline & AVERAGE OBEDIENCE & \multicolumn{2}{|c|}{$30 \%$} & \multicolumn{2}{|c|}{$50 \%$} & \multicolumn{2}{|c|}{$50 \%$} & \multicolumn{2}{|c|}{$30 \%$} & \multicolumn{2}{|c|}{$10 \%$} & \multicolumn{2}{|c|}{$30 \%$} & \\
\hline
\end{tabular}

\section{CONCLUSION}

From the analysis and discussion of the new normal adaptation conditions in several traditional markets, the following conclusions are drawn:

1. All markets have provided hand washing facilities equipped with soap, but some markets do not pay attention to the availability of water for hand washing.

2. Problems that are very difficult to implement include; application of social distancing among market visitors due to the small dimensions of the circulation space for market visitors due to narrow circulation space and space narrowing caused by traders placing their merchandise; there is no sign that prevents visitors from maintaining a safe distance and also orderly in using stairs with up and down paths; and there is no partition divider used to separate the distance between traders inside the market stalls.

3. Disobedient behavior of the public and traders in using masks or face shields as personal protective equipment in accordance with health protocols directed by the government.
4. The market with the main two-story building tends to have good ventilation and natural lighting, with an atrium in the middle of the building as well as a fairly

high roof, and the use of a roof with a transparent material.

5. Most markets have provided drain for disposal of market waste, but the problem is that Wastewater Treatment Plant (WWTP) is not yet available to treat slaughter animal waste, and sewage that is not closed creates a strong odor in the market.

\section{RECOMMENDATION}

Several directions for improving conditions and the concept of a healthier market in order to support directions for implementing health protocols in traditional markets, namely

\section{Physical activity recommendations:}

a. Regulate and ensure the minimum width of circulation space (opposite stalls, dominant seated, standing transactions, one-sided stalls and booths) is $170-305$ $\mathrm{cm}$ equipped with markers.

b. Sign the stairs for up and down circulation.

c. Provide transparent bulkheads for traders in the booths. 
d. Adjust the operating hours of booths or move temporarily traders to open areas (provided distance).

e. Close sewage drain and provide Wastewater Treatment Plant (WWTP) at market locations.

f. Require and make higher roofs of buildings, and the use of cross-ventilation of buildings above corridors, or application of atrium spaces in the center of market buildings.

g. Use transparent roofs for direct lighting or use roof gaps for indirect lighting along corridors.

Non-physical activity recommendations:

a. Provide regular coaching to traders and market visitors regarding health protocol disciplines such as using of masks or face shields, hand washing, spacing, and using of stairs.

b. Order merchants who use circulation space to place their merchandise.

\section{REFERENCES}

[1] Dyah Ayu Permata Hari, I. M. (2014). Perancangan Kembali Pasar Setonobetek Kota Kediri (Penerapan Pola Tata Ruang dan Pemilihan Maaterial yang Mengacu pada Peraturan Pasar Sehat).

[2] Indonesia, M. K. (2020). Keputusan Menteri Kesehatan Republik Indonesia Nomor HK.01.07/MENKES/382/2020 Tentang Protokol Kesehatan Bagi Masyarakat di Tempat dan Fasilitas Umum Dalam Rangka Pencegahan dan Pengendalian Corona Virus Disease 2019 (covid-
19). Jakarta: Kementerian Kesehatan Republik Indonesia .

[3] Julius Panero, M. Z. (2003). Dimensi Manusia dan Ruang Interior. Jakarta: Erlangga.

[4] Kementerian Kesehatan Republik Indonesia. (2020). Keputusan Menteri Kesehatan Ri Nomor HK.01.07/MENKES/382/2020 Tentang Protokol Kesehatan Bagi Masyarakat Di Tempat dan Fasilitas Umum Dalam Rangka Pencegahan dan Pengendalian Corona Virus Disease 2019 (Covid19). Jakarta : Kemenkes RI.

[5] Latifah, N. L. (2015). Fisika Bangunan 1. Jakarta: Griya Kreasi

[6] Latifah, N. L. (2015). Fisika Bangunan 2. Jakarta: Griya Kreasi.

[7] Pemerintah Republik Indonesia. (2014). PP nomor 101 Tahun 2014 tentang Pengelolaan Limbah Bahan Berbahaya dan Beracun. Jakarta: Kementerian Sekretariat Negara Republik Indonesia .

[8] Steward Rahantoknam, L. T. (n.d.). Pemanfaatan Ruang Para Pedagang di Pasar Tradisional Bahu Manado dan Pengaruhnya Terhadap Kondisi Aksesibilitas Kawasan. 131-141.

[9] Wasilah, A. R. (2017). PAsar Tradisional Dengan Penataan Modern di Kota Makassar. National Academic Journal of Architecture, 11-20. 